\title{
The Effects of Cage Exchange on the Marking Behavior of Male Domestic Rabbits
}

\author{
Yasuo Matsuzawa and Junko OHкоshi \\ Faculty of Agriculture, Ibaraki University, \\ Ami-machi, Ibaraki-ken 300-03
}

(Received October 7, 1992)

\begin{abstract}
The effects of cage exchange on marking behavior were studied using three adult male Japanese White rabbits caged individually. In its own home cage every rabbit tended to excrete at almost the same site through seven or eight $24 \mathrm{~h}$ period observations and the overall agreement of both defecation and urination sites for each animal during these days was statistically significant $(\mathrm{P}<0.001)$. Then, they were individually introduced into an empty cage in which another rabbit had been kept until that time. Immediately after the cage exchange every rabbit began to sniff at the inside of the cage and performed much more frequent defecation, urination, chinning and pawing behavior within the first ten minutes in comparison with the following hours. As a result, the peculiar pattern of excretion site for each rabbit that had been seen in its home cage was temporarily broken down, but thereafter it was gradually recovered and regained almost perfectly within 24 hours. In contrast to this, when each rabbit was returned to its own cage after one minute without cage exchange, marking behavior was hardly observed.
\end{abstract}

Anim. Sci. Technol. (Jpn.) 64 (10) 992-1000, 1993

Key words : marking behavior, odour, defecation, urination, rabbit

Olfaction plays an important role in the social life of the wild rabbit, Oryctolagus cuniculus. The rabbit has two scent glands, chin or submandibular gland and anal gland, which are associated with social dominance and territoriality ${ }^{10-16)}$. It deposits the secretion of the chin gland by rubbing its chin against an object in the environment ${ }^{9,11,12,15}$ and this marking behavior has been called chinning ${ }^{9}$. The rabbit also deposits the secretion of the anal gland with its feces and piles up the marked feces at prominent locations in its home range ${ }^{10,13,15,16)}$. It seems that the rabbit learns to recognize the odour of the mother's anal gland during its earliest life and may recognize the role of the feces in defining its territorial boundaries during this nesting period $^{15,17)}$. According to MYкYтOWYCz ${ }^{14,15)}$, a rabbit uses both glands, as well as urine, to mark its territory. Both chin and anal glands are larger in males than in females and in dominant males than in subordinate males, and individuals with large glands mark more frequently than those with small ones do ${ }^{4,11-15)}$.

Wild $^{3,9)}$ and domestic ${ }^{5)}$ rabbits oftern paw vigorously at the ground with their front legs. Similar behavior has been observed in many other mammal, and is thought to be a threatening display toward conspecifics ${ }^{19)}$. Pawing behavior may serve not only as a threatening display but also as a visual marking as thought for some ungulates ${ }^{8,19)}$ and carnivora ${ }^{22)}$, 
since the scrapes made on the ground are of ten visible to observers at a considerable distance.

Domestic rabbits in a laboratory are forced to live in a man-made environment and are usually isolated in a cage, where they have little opportunity to contact their conspecifics, and the natural odour of animals tends to be artificially eliminated for reasons of hygiene or convenience. It is, however, said that the characteristic patterns of behavior of a species are so stable that in some instances they have served as major criteria in taxonomically classifying various related species of animals ${ }^{6}$. In fact, it is, for example, often observed that domestic rabbits void their droppings at one particular site, such as the corner of a cage, just as wild rabbits mark at boundaries of their territory.

In this paper we deal with changes in marking behavior including defecation, urination, chinning and pawing (scratching) by a male domestic rabbit caged in a laboratory, accompanied by cage exchange treatment. The aim is to investigate what behavioral significance the environmental odour derived from themselves has for rabbits kept in an artificial environment, and to contribute to the assessment and review of the laboratory animal's environment, particularly the olfactory environment, from the viewpoint of animal welfare.

\section{Materials and Methods}

Three male Japanese White rabbits aged eight to nine months were used. Rabbits A, B and $C$ weighed $3.9,3.5$ and $3.6 \mathrm{~kg}$ respectively, and were kept individually in commercial rabbit cages $(50 \mathrm{~cm}$ long, $38 \mathrm{~cm}$ wide, $35 \mathrm{~cm}$ high) 1,2 and 3 placed at a distance of two meters apart from each other, respectively.

18 plastic cases (inside dimensions $8.0 \mathrm{~cm}$ wide, $10.8 \mathrm{~cm}$ long, $3.2 \mathrm{~cm}$ high) were put compactly in 6 rows and 3 columns under the wire mesh floor of each cage in order to receive feces and urine. We could ascertain where and how much a rabbit excreted by measuring the feces (number of pellets) and urine (volume in gram) in each plastic case. The quantity of excretions in peripheral cases, which covered 1.2 times the area of central cases, was adjusted as compared with the central cases. When feces had mingled with urine in a plastic case, the urine amount was calculated by subtracting the weight value equal to 0.4 times number of feces from the gross weight since the average weight of a feces pellet was $0.4 \mathrm{~g}$.

In order to certify the constancy of excretion site for each rabbit, 24 hour-experiments to measure the amount of excretion into each plastic case were repeated eight times for rabbit $A$ and rabbit $B$, and seven times for rabbit $C$, over an 80-day period from July to September.

Cage exchange experiments were performed four times for each animal and two times with the same partner; namely, 12 times in total (see Table 2). After each rabbit had been kept in its home cage for ten days (cage 1 for rabbit A ; cage 2 for rabbit $B$; cage 3 for rabbit $C$ ), rabbit $A$ was introduced into cage 2 , rabbit $B$ into cage 3 and rabbit $\mathrm{C}$ into cage 1 , in turn. The quantities of excreta in plastic cases were measured for ten minutes before the exchange of cage, and ten minutes, 1 hour and 24 hours after the exchange of cage. Following this first cage exchange test, each rabbit was replaced into its own cage and kept there for 5 days. Then, second cage exchange treatment and measurement were performed via the same procedure as for the first test.

As a control test, a rabbit was put out of the home cage for one minute and thereafter returned to the home cage, and the amount of excreta was measured by the procedure mentioned above. This test was performed seven times, two times for rabbit $\mathrm{A}$ and rabbit $B$, and three times for rabbit $C$.

The observations of chinning and pawing behavior were performed through 24 hour video-recording under the same cage exchange 
conditions as mentioned above. These observations were carried out four times for each animal; namely, 12 times in total. The number of chinnings was counted as the number of times that a rabbit actually rubbed its chin on objects such as the food hopper inside of the cage, and so on. The number of pawings was counted as the number of bouts of scratching by both front feet with an interval of less than three seconds.

For statistical analysis, Kendall's $W^{20)}$ was calculated in order to compare the excreta distribution patterns before the cage exchange with that after the cage exchange.

\section{Results}

\section{Excretion site of each rabbit}

The floor of each cage was divided into nine blocks by considering the two lengthwise adjacent plastic cases as one block, and the amounts of feces and urine emitted into each block within 24 hours were measured.

As a result, it was shown that the excreta distribution pattern for each rabbit in its cage was almost constant throughout the observation period. The results for rabbit $\mathrm{A}$ heve been put into Table 1, with excreta amounts being transformed into rankings. To quantify the overall agreement between observations for each animal, Kendall's coefficient of concordance (W) was used and its statistical significance was tested by the chi square test $\left(\chi^{2}=\mathrm{k}(\mathrm{N}-1) \mathrm{W}\right.$, where $\mathrm{k}$; sets of rankings, $\mathrm{N}$; number of blocks). As shown in Table 1, both indexes of concordance of defecation site and urination site for rabbit A showed highly significant agreement as the values of Kendall's $W$ were $0.789\left(\chi^{2}=50.47, p<0.001\right)$ for the former and $0.602\left(\chi^{2}=38.52, p<0.001\right)$ for the latter. Similarly, both rabbits $B$ and $C$ tended to emit at a regular place in the cage (defecation site; $W=0.666, \chi^{2}=42.64$ for rabbit $B$, and $W=0.862, \chi^{2}=48.25$ for rabbit $C$, urination site; $W=0.563, \chi^{2}=36.01$ for rabbit $B$, and $W=0.458, \chi^{2}=25.63$ for rabbit $C, p<0.001$ for the first three values and $\mathrm{p}<0.005$ for the last value).

2. Effects of cage exchange on the excretion pattern

1) Amount of feces and urine excreted

As shown in Table 2, both quantities of defecation and urination for every animal had a tendency to be greatest within the first ten minutes after the cage exchange and to decrease suddenly thereafter. The average amounts of feces and urine emitted within this ten minutes were 26.3 pellets and $14.8 \mathrm{~g}$, which occupied $11.7 \%$ and $8.7 \%$ of the total amount

Table 1. Ranking of the amount of feces and urine excreted at each block under the cage floor (instance of rabbit $\mathrm{A}$ )

No. of measurements

\begin{tabular}{cllllllllllllllll}
\cline { 2 - 13 } & \multicolumn{11}{c}{ Defecation } & \multicolumn{10}{c}{ Urination } \\
\hline Block & 1 & 2 & 3 & 4 & 5 & 6 & 7 & 8 & 1 & 2 & 3 & 4 & 5 & 6 & 7 & 8 \\
\hline 1 & 4 & 2 & 2 & 2 & 1.5 & 2 & 5 & 2 & 5 & 3 & 2.5 & 2 & 4 & 2 & 7 & 1 \\
2 & 2 & 4 & 3 & 4 & 5.5 & 4 & 3 & 4 & 7.5 & 5.5 & 4.5 & 7 & 6.5 & 4 & 7 & 7.5 \\
3 & 3 & 3 & 4 & 3 & 3 & 3 & 4 & 7.5 & 7.5 & 5.5 & 7.5 & 7 & 6.5 & 7 & 3.5 & 7.5 \\
4 & 1 & 1 & 1 & 1 & 1.5 & 1 & 1 & 1 & 3.5 & 2 & 2.5 & 7 & 2 & 3 & 7 & 4 \\
5 & 5 & 6 & 5 & 6 & 4 & 5 & 7 & 6 & 2 & 8.5 & 7.5 & 4 & 3 & 7 & 7 & 5 \\
6 & 6 & 7 & 6 & 5 & 7 & 6 & 6 & 5 & 7.5 & 8.5 & 7.5 & 7 & 9 & 7 & 7 & 7.5 \\
7 & 7 & 5 & 8 & 7 & 8.5 & 8.5 & 2 & 3 & 1 & 1 & 1 & 1 & 1 & 1 & 1 & 3 \\
8 & 8.5 & 9 & 8 & 9 & 5.5 & 7 & 8 & 7.5 & 3.5 & 5.5 & 4.5 & 3 & 6.5 & 7 & 2 & 2 \\
9 & 8.5 & 8 & 8 & 8 & 8.5 & 8.5 & 9 & 9 & 7.5 & 5.5 & 7.5 & 7 & 6.5 & 7 & 3.5 & 7.5 \\
\hline
\end{tabular}


Table 2. Increase of the cumulative amount of exceta accompanied by the cage exchange and the subsequent transition (average of two measurements for every one resident rabbit)

\begin{tabular}{|c|c|c|c|c|c|c|c|}
\hline \multicolumn{2}{|c|}{ Rabbit } & \multicolumn{6}{|c|}{ Time after cage exchange } \\
\hline Subject & Resident & $-10 \mathrm{~min}$ & $10 \mathrm{~min}$. & & our & $24 \mathrm{hc}$ & our \\
\hline \multicolumn{8}{|c|}{ Feces (no. pellets) } \\
\hline A & $\stackrel{B}{\mathrm{C}}$ & $\begin{array}{l}0 \\
0\end{array}$ & $\begin{array}{l}31 \\
40\end{array}$ & $\begin{array}{l}49 \\
55\end{array}$ & $\begin{array}{l}(8.2)^{*} \\
(9.2)\end{array}$ & $\begin{array}{l}210 \\
183\end{array}$ & $\begin{array}{l}(1.5)^{*} \\
(1.3)\end{array}$ \\
\hline B & $\begin{array}{l}\mathrm{A} \\
\mathrm{C}\end{array}$ & $\frac{1}{3}$ & $\frac{1}{22}$ & $\begin{array}{l}17 \\
35\end{array}$ & $\begin{array}{l}2.8) \\
(5.8)\end{array}$ & $\begin{array}{l}243 \\
250\end{array}$ & $(1.7)$ \\
\hline C & $\begin{array}{l}\mathrm{A} \\
\mathrm{B}\end{array}$ & $\begin{array}{l}0 \\
0 \\
\end{array}$ & $\begin{array}{l}48 \\
56 \\
\end{array}$ & $\begin{array}{l}57 \\
60 \\
\end{array}$ & $\begin{array}{r}(9.5) \\
(10.0) \\
\end{array}$ & $\begin{array}{l}188 \\
280\end{array}$ & $\begin{array}{l}(1.3) \\
(1.9)\end{array}$ \\
\hline \multicolumn{2}{|c|}{ Mean } & 0.7 & 26.3 & \multicolumn{2}{|c|}{$45.5(7.6)$} & \multicolumn{2}{|c|}{$225.7(1.6)$} \\
\hline \multicolumn{8}{|c|}{ Urine $(\mathrm{g})$} \\
\hline A & $\stackrel{B}{C}$ & $\begin{array}{l}0 \\
0\end{array}$ & $\begin{array}{l}27.5 \\
26.2\end{array}$ & \multicolumn{2}{|c|}{$\begin{array}{l}28.0(4.7)^{*} \\
43.8(7.3)\end{array}$} & \multicolumn{2}{|c|}{$\begin{array}{l}214.2(1.5)^{*} \\
202.0(1.4)\end{array}$} \\
\hline B & $\stackrel{A}{C}$ & $\begin{array}{l}1.0 \\
0\end{array}$ & $\begin{array}{l}7.8 \\
1.0\end{array}$ & \multicolumn{2}{|c|}{$\begin{array}{r}25.7\left(\begin{array}{l}4.3) \\
3.5\end{array}(0.6)\right.\end{array}$} & \multicolumn{2}{|c|}{$\begin{array}{l}199.6(1.4) \\
184.3(1.3)\end{array}$} \\
\hline $\mathrm{C}$ & $\begin{array}{l}\mathrm{A} \\
\mathrm{B}\end{array}$ & $\begin{array}{l}0 \\
0 \\
\end{array}$ & $\begin{array}{r}9.4 \\
16.6 \\
\end{array}$ & \multicolumn{2}{|c|}{$\begin{array}{r}9.5(1.6) \\
16.6(2.8)\end{array}$} & \multicolumn{2}{|c|}{$\begin{array}{l}115.2(0.8) \\
104.5(0.7)\end{array}$} \\
\hline \multicolumn{2}{|c|}{ Mean } & 0.2 & 14.8 & \multicolumn{2}{|c|}{$21.2(3.5)$} & \multicolumn{2}{|c|}{$170.0(1.2)$} \\
\hline
\end{tabular}

* per $10 \mathrm{~min}$.

Table 3. Similarities of the excreta distribution patterns ${ }^{1)}$, which were indicated by Kendall's $W$ (coefficient of concordance), between the resident and the subject before or after the cage exchange

\begin{tabular}{|c|c|c|c|c|c|}
\hline \multirow{3}{*}{ Subject } & \multirow{3}{*}{ Resident } & \multicolumn{4}{|c|}{ Kendall's W } \\
\hline & & \multicolumn{2}{|c|}{ Resident vs 10 min. after ${ }^{2)}$} & \multicolumn{2}{|c|}{ Before vs $24 \mathrm{hr}$ after ${ }^{33}$} \\
\hline & & Defecation & Urination & Defecation & Urination \\
\hline A & $\begin{array}{l}\mathrm{B} \\
\mathrm{B}\end{array}$ & $\begin{array}{l}0.737 \\
0.662\end{array}$ & $\begin{array}{l}0.619 \\
0.367\end{array}$ & $\begin{array}{l}0.939 \\
0.975^{*}\end{array}$ & $\begin{array}{l}0.792 \\
0.798\end{array}$ \\
\hline B & $\begin{array}{l}C \\
C\end{array}$ & $\begin{array}{l}0.738 \\
0.530\end{array}$ & $\begin{array}{l}0.865 \\
0.813\end{array}$ & $\begin{array}{l}0.906 \\
0.792\end{array}$ & $\begin{array}{l}0.821 \\
0.572\end{array}$ \\
\hline C & $\begin{array}{l}A \\
A\end{array}$ & $\begin{array}{l}0.588 \\
0.698\end{array}$ & $\begin{array}{l}0.626 \\
0.729\end{array}$ & $\begin{array}{l}0.896 \\
0.921\end{array}$ & $\begin{array}{l}0.767 \\
0.591\end{array}$ \\
\hline
\end{tabular}

1) Patterns of excretion at nine blocks under the cage foor in the same way as in Table 1.

${ }^{2)}$ Comparison between pattern of resident before cage exchange and that of subject for 10 minutes after cage cxchange.

${ }^{3)}$ Comparison between pattern of subject before cage exchange and that of subject for 24 hours after cage exchange.

${ }^{*} \mathrm{P}<0.05$

in a whole day, respectively. The former reached 3.5 times and 16.4 times per unit time as many as the amounts emitted within one hour and within 24 hours after the cage exchange, respectively, and the latter reached 4.2 times and 12.3 times in turn, respectively.
In contrast to this, when rabbits were returned to their own cages after one minute without exchanging cages, neither defecation nor urination were found at all within ten minutes immediately after being returned, while only one to three feces were found after 1 


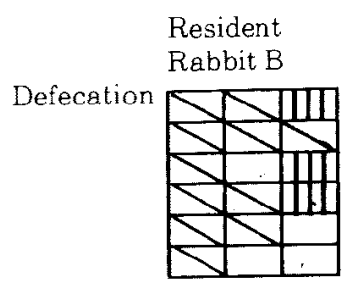

Rabbit A

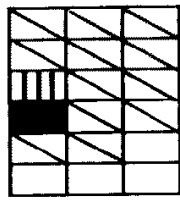

Rabbit B

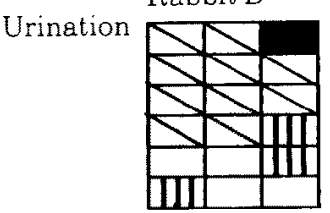

Rabbit A

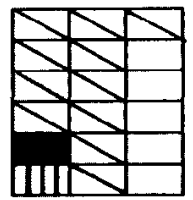

Subject

Rabbit A
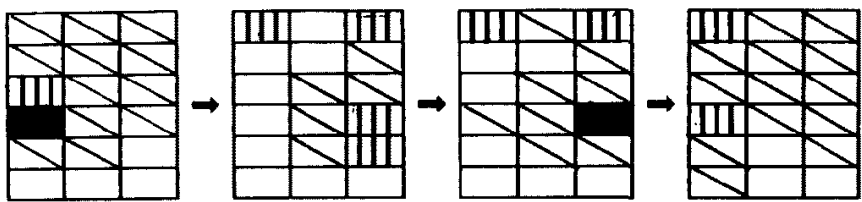

Rabbit C
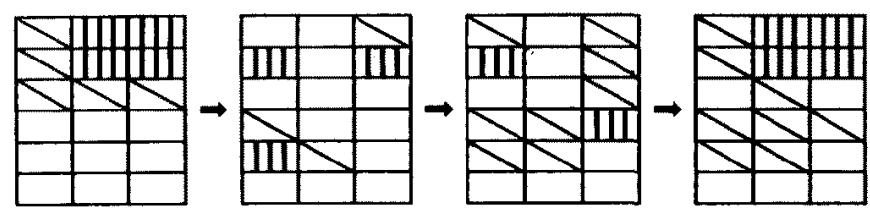

Rabbit A
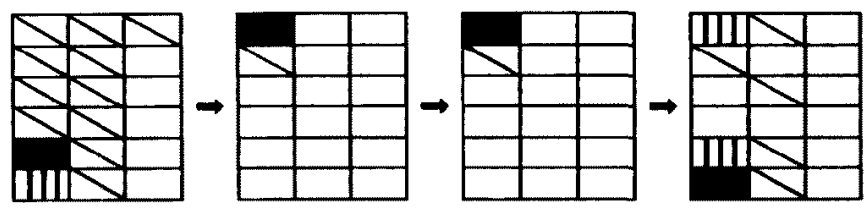

Rabbit C
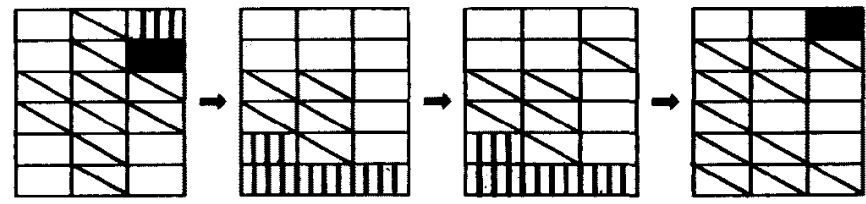

Before exchage

After 1 hour After 24 hours

Fig. 1. Some examples of transition of excreta distribution patterns accompanied by the cage exchange.

Percentage of amounts of excreta:

above $40 \%$, III 10-39\%, $\square$ under $9 \%, \square$ none

hour in a total of 8 measurements for three animals.

2) Excretion pattern

The cage exchange also affected excretion sites for both defecation and urination. Together with the excreta distribution patterns of the resident animals just before the cage exchange, some typical examples of transition of excreta distribution patterns that the newcomers exhibited after the cage exchange are shown in Fig. 1. Every rabbit tended to exhibit a similar pattern to that of the resident immediately after the cage exchange, but thereafter they gradually returned to their own peculiar patterns. In order to confirm this tendency, the similarity of the excreta distribution patterns of the resident and the subject before and after the cage exchange was examined using the above-mentioned Kendall's W (Table 3). As a result, although most of the values of Kendall's W were statistically insignificant, since the numbers of both variance $(\mathrm{k}=2)$ and data $(\mathrm{N}=9)$ were small, it was shown that the values were fairly high for both defecation and urination. Therefore, the excretion pattern of the subject for 10 minutes 
Table 4. Increase of the cumulative number of occurrences of the chinning and pawing accompanied by the cage exchange and the subsequent transition (average of two measurements)

\begin{tabular}{|c|c|c|c|c|c|c|c|c|c|}
\hline \multirow{2}{*}{\multicolumn{2}{|c|}{ Rabbit }} & \multicolumn{8}{|c|}{ Time after cage exchange } \\
\hline & & \multirow{2}{*}{\multicolumn{2}{|c|}{$\frac{-10 \mathrm{~min} .}{\text { chinning pawing }}$}} & \multicolumn{2}{|c|}{$10 \mathrm{~min}}$. & \multicolumn{2}{|c|}{1 hour } & \multicolumn{2}{|c|}{24 hour } \\
\hline Subject & Resident & & & chinning & pawing & chinning & pawing & chinning & pawing \\
\hline $\mathrm{A}$ & $\stackrel{\mathrm{B}}{\mathrm{C}}$ & $\begin{array}{l}0 \\
0\end{array}$ & $\begin{array}{l}0 \\
0\end{array}$ & $\begin{array}{l}29 \\
13\end{array}$ & $\begin{array}{r}5 \\
14\end{array}$ & $\begin{array}{l}29 \\
14\end{array}$ & $\begin{array}{r}5 \\
14\end{array}$ & $\begin{array}{l}29 \\
14\end{array}$ & $\begin{array}{r}5 \\
14\end{array}$ \\
\hline B & $\begin{array}{l}\mathrm{A} \\
\mathrm{C}\end{array}$ & $\begin{array}{l}0 \\
0\end{array}$ & $\begin{array}{l}0 \\
0\end{array}$ & $\begin{array}{l}5 \\
3\end{array}$ & 1 & $\begin{array}{l}5 \\
3\end{array}$ & $\begin{array}{l}1 \\
0\end{array}$ & $\begin{array}{l}5 \\
3\end{array}$ & $\begin{array}{l}1 \\
0\end{array}$ \\
\hline $\mathrm{C}$ & $\begin{array}{l}\mathrm{A} \\
\mathrm{B}\end{array}$ & $\begin{array}{l}0 \\
0\end{array}$ & $\begin{array}{l}0 \\
0\end{array}$ & $\begin{array}{l}40 \\
73\end{array}$ & $\begin{array}{r}6 \\
29\end{array}$ & $\begin{array}{l}42 \\
73\end{array}$ & $\begin{array}{r}9 \\
29\end{array}$ & $\begin{array}{l}42 \\
73\end{array}$ & $\begin{array}{r}9 \\
29\end{array}$ \\
\hline \multicolumn{2}{|c|}{ Mean } & 0 & 0 & 27.2 & 9.2 & 27.7 & 9.7 & 27.7 & 9.7 \\
\hline
\end{tabular}

after the cage exchange was similar to that of the resident before the cage exchange, and the pattern of the subject 24 hours after cage exchange became similar to its own peculiar pattern before the cage exchange, especially for defecation.

\section{Other marking behavior}

In regard to the marking behavior of rabbits, chinning and pawing were observed in addition to defecation and urination. Immediately after the cage exchange, the rabbits usually sniffed all over the inside of the cage and chinned frequently, especially at the food hopper, except for the roof of the cage. The first chinning was observed within the first minute in all 12 cases. Pawing means that the rabbit scratched the cage floor speedily with his front feet. Occasionally, pawing also followed sniffings by which defecation or urination were followed without exception.

Table 4 shows the frequency of chinning and pawing observed before and after the cage exchange. No rabbit conducted chinning or pawing within ten minutes before the cage exchange at all, but within the first ten munutes after the cage exchange the rabbits conducted most of the total occurrences within the subsequent 24 hours. But this behavior was rare in rabbit $\mathrm{B}$.

No chinning or pawing were observed when the animals were again replaced into their own cages after one minute instead of the cage exchange.

\section{Discussion}

In this study we found that both the defecation and urination sites for each rabbit were consistently almst fixed in the cage. This seemed to result from the territorial marking of each animal rather than from a decision regarding "latrine" site for sanitation, for the following reasons. First, every rabbit excreted close to the excretion site of the resident animal initially when placed in an empty cage which had belonged to the latter, and thereafter transfered its excretion site to its own proper site. And moreover, according to our unpublished observatios, when two individual cages were put in the vicinity of each other, each rabbit in the cage excreted more frequently at sites in the cage close to the opponent.

From these findings, it seems customary also for a rabbit kept individually in a cage to perform territorial marking as a wild rabbit does in natural conditions.

It has been suggested that, within the space in which their own or a familiar odour prevails, wild rabbits behave more confidently and tend to dominate individuals isolated from their own odour ${ }^{18,19}$. Thus, the presence of its own odour can give a rabbit a psychological advantage and in the absence of its own odour 
an animal feels ill at ease. Hesterman and Myкитоwyc ${ }^{4)}$ showed that rabbits defecated and chinned when a cloth impregnated with the smell of a strange rabbit was put into their cage.

In the present study, most marking behavior was performed within ten minutes after the cage exchange treatment. This shows that a novel environment saturated with the odour of other rabbits is a stimulation which induces marking behavior. It is evident that the motivating stimulation was the odour since the home cage of the subject was identical in both size and structure to a new cage, and the animals always sniffed elaborately inside the new cage prior to marking. It is considered that they marked in order to replace the odour of the resident with their own, which brought them psychological stability.

The cage exchange also induced chinning and pawing. Chinning is a method of territorial marking by means of the secretion of a chin gland, and it is a common activity of foreign males entering strange territory ${ }^{9,19)}$. It is also performed especially by sexually acitve wild male rabbit in conjunction with the search for a female in oestrus ${ }^{9,11,12}$. Pawing has been considered a displacement activity, characterized by a furious scratching of the ground and observed usually when in the presence of a rival male or a female in oestrus in wild rabbits ${ }^{9}$. MeiJsser et al. ${ }^{\text {") }}$ estimated pawing as the factor which characterized "prudence" by factor analysis in psychological experiments. Pawing may be also an act to mark visually by digging traces. Some ungulates, before or after pawing, usually urinate in the scrape and it becomes identifiable by both visual and olfactory signals ${ }^{8}$.

In any case, behavior like chinning and pawing appears to be a sign of high excitement or tension.

Form the facts described above, it is concluded that the cage exchange brought rabbits to an initial state of excitement or anxiety and subsequently produced marking bahavior for restoration of psychological stability. If environmental animal odour can change responsiveness to various stimuli and influence the physiological state of many species ${ }^{1,2,18,20)}$, more concern should be directed at environmental odour around domestic rabbits isolated in a cage.

The marking behavior of the rabbits observed in this study may be considered as adaptive behavioral responses for control and establishment of their own favourable environment, originating from an emotional tension. Therefore, when the exchange, washing and rearrangement of cages are carried out excessively as routine work in a laboratory, the environmental conditions which have been established before such treatments may be disrupted, and consequently, the welfare of rabbits may be impaired.

\section{References}

1) Bronson, F.H., Effects of social stimulation on adrenal and reproductive physiology of rodents. in Husbandry of Laboratory Animals, 3rd Symposium of the International Committee on Laboratory Animals (ConalTY, M.L. eds.) 513-542. Academic Press. London. 1967.

2) BRUCE, H.M., Olfactory block to pregnancy among grouped mice. J. Reprod. Fert., 6 : 451-460. 1963.

3) Cowan, D., The wild rabbit. 16-15. Blandford Press. Poole, Dorset. 1980.

4) Hesterman, E.R. and R. Mykytowycz, Some observations on the odours of anal gland secretions from the rabbit, Oryctolagus cuniculus (L.). CSIRO Wildl. Res., 13: 71-81. 1968.

5) KawaI, M., On the relation between the exploring behavior in the strange place and the dominance subordination of rabbit. Annual Anim. Psychol., 4: 17-25. 1954. (in Japanese)

6) Kretchmer, K.R. and M.W. Fox, Effects of domestication on animal behaviour. Vet. Rec., 96 : 102-108. 1975.

7) Meijsser, F.M., A.M.P. Kersten, P.R. WiEPKEMA and J.H.M. Metz, An analysis 


\section{Marking Behavior of Male Domestic Rabbit}

of the open-field performance of sub-adult rabbits. Appl. Anim. Behav. Sci., 24 : 147155.1989.

8) Moore, W.G. and R.L. Marchinton, Marking behavior and its social function in white-tailed deer. in The behaviour of ungulates and its relation to management (Geist V. and F. WALther ed.) 447-456. IUCN publications new series No. 24, Morges. 1974.

9) Myers K. and W.E. PoOle, A study of the bilolgy of the wild rabbit, Oryctolagus cuniculus (L.), in confined populations. II. The effects of season and population increase on behaviour. CSIRO Wildl. Res., 6 : 1-41. 1961.

10) Mүкүтошусz, R., Social behaviour of an experimental colony of wild rabbits, Oryctolagus cuniculus (L.). II. First breeding season. CSIRO Wildl. Res., 4: 1-13. 1959.

11) MүкүтошусZ, R., Territorial function of chin gland secretion in the rabbit, Oryctolagus cuniculus (L.). Nature, 193: 799. 1962.

12) Myкүтошусz, R., Further observation on the territorial function and histology of the submandibular cutaneous (chin) glands in the rabbit. Anim. Behav., 13:400-412. 1965.

13) Мүкутошусz, R., Observations on odoriferous and other glands in the Australian wild rabbit, Oryctolagus cuniculus (L.), and the hare, Lepus enropaeus (P.). I. The anal gland. CSIRO Wildl. Res., 11 : 11-29.
1966.

14) Mykytowycz, R. and M.L. Dudzinski, A study of the weight of odoriferous and other glands in relation to social status and degree of sexual activity in the wild rabbit, Oryctolagus cuniculus (L.). CSIRO Wildl. Res., 11: 31-47. 1966.

15) Myкүтошчcz, R., Territorial marking by rabbits. Sci. Ame., 218: 116-126. 1968.

16) Mykytowycz, R. and S. Gambale, The distribution of dung-hills and the behaviour of free-living wild rabbits, Oryctolagus cuniculus ( $\mathrm{L}$.$) , on them. forma et$ functio. $1: 333-349.1969$.

17) Mүкүтошчcz, R. and M.M. WARD, Some reactions of nestlings of the wild rabbit, Oryctolagus cuniculus (L.), when exposed to natural rabbit odours. forma et functio, 4: 137-148. 1971.

18) Myкттоwycz, R., Reproduction of mammals in relation to environmental odours. J. Reprod. Fert., Suppl., 19: 433-446. 1973.

19) RAl.LS K., Mammalian scent marking. Science, $171:$ 443-449. 1971.

20) Sieged, S., Nonparametric statistics for the behavioral science (translated by Fusımoto, H. et al). 236-246. McGraw-Hill Book Co. Tokyo. 1983. (in Japanese).

21) Signoret, J.P., Reproductive behaviour of pigs. J. Reprod. Fert., Suppl., 11 : 105-117. 1970.

22) SмIтH, W.J., The behavior of communicating. 253-258. Harvard University Press. Cambridge. 1977. 


\title{
雄ウサギのマーキング行動に及ぼすケージ 交換の影響
}

\author{
松沢安夫 ·大越純子
}

茨城大学農学部, 茨城県阿見町 300-03

\begin{abstract}
日本白色種の雄の成ウサギ 3 顽を単飼ケージで飼育し、マーキング（包いづけ）行動へのケージ交換 の影響を調べた，各ケージの金網床の下に 18 個のプラスチックケースを敷き亚べて，排翼・排㲾の位 置之量を経時的に求めた。 24 時間ずつ 8 问の観察においてケージ内での排䔬・排尿の位置は個体ごと にほぼ一定して㧍り，その一致度（Kendall の一致度係数）は統計的に有意であった $(\mathrm{P}<0.001) .3$ 頭閒で互いにケージ交換テストを計 12 回行なった。 どの個体も交換後 10 分以内に包いかぎに続いて頻 繁な排翼・排尿は行ない，1個体を除いてチンニング（下顎腺のこすりつけ行動），前掻きも頻繁に観 察さ机た，その後，これらの行動は急速に減少した，ヶージ交換により，各個体の一定の排粪・排尿の 位置パターンは一時的に崩れたが，24時間後には本来のパターンに復帰した。ウサギをケージ外に短 時開出したのちに元のケージに戻した場合には，以上のような現象は認められなかった。
\end{abstract}

日蓄会報, $64(10): 992-1000,1993$ 